\title{
Радіоактивність бетонів як багатокомпонентних будівельних матеріалів
}

\author{
Е.Б. Хоботова ${ }^{1}$, І.В. Грайворонська ${ }^{2}$, М.М. Кірієнко ${ }^{3}$ \\ 1, 2 Харківський начіональний автомобільно-дорожній університет, \\ (м. Харків, Україна) ${ }^{1}$ email: elinahobotova@gmail.com, ORCID:0000-0001-6377-5186; \\ 2 email: inna_gra@ukr.net; ORCID:0000-0002-8537-0435 \\ ${ }^{3}$ Харківський національний технічний університет сільського господарства \\ імені Петра Василенка, (м. Харків, Україна) \\ email: hfinpomt@ukr.net, ORCID: 0000-0003-2573-9189
}

\begin{abstract}
Оцінка радіоактивності і радіологічних небезпек, пов'язаних з багатокомпонентними будівельними матеріалами $є$ необхідною, так як останнім часом у виробництві будівельних матеріалів використовуються промислові відходи, які можуть бути концентраторами природних радіонуклідів. Будівельні матеріали є джерелами ү-випромінювання і надходження радону. Проблема дослідження - радіоактивні властивості багатокомпонентних бетонів і розрахунок дозових навантажень для людини при використанні бетонів. Гамма-спектрометричним методом визначено питомі активності 226Ra, 232Th та 40K в 7 зразках бетону. За величиною ефективної питомої активності Сеф.<370 Бк/кг досліджувані зразки бетону відносяться до I класу радіаційної небезпеки і можуть використовуватися в будівництві без обмежень. Ефективна еквівалентна доза опромінення за 50 років для людей, які проживають в бетонних приміщеннях, менше сумарної дози опромінення населення за рахунок природних радіонуклідів і проведення медичних процедур 170 мЗв. Однак по розрахованим середнім річним тканинним (легеневим) доз опромінення людини за рахунок радону для вентильованих і не вентильованих приміщень і по величині дози за рахунок ү-випромінювання виявлено зразки бетонів, які не можуть бути рекомендовані до застосування в цивільному будівництві. Показано, що за даними про радіоактивність зразків і масового вкладу їх окремих компонентів можливо визначити варіювання змісту інших компонентів бетону. Будівельні матеріали $\epsilon$ джерелами радону всередині будівель. Радіонукліди радону і їх дочірні продукти розпаду обумовлюють ризик опромінення через альфа-випромінювання.
\end{abstract}

Ключові слова: природні радіонукліди, ефективна питома активність, бетон, гаммавипромінювання, еманація радону.

Вступ. Природний радіаційний фон в значній мірі обумовлений радіонуклідами: ${ }^{232} \mathrm{Th}$ та ${ }^{238} \mathrm{U}$ та їх продуктами розпаду, а також ${ }^{40} \mathrm{~K}$, що існують на слідових рівнях в земній корі. Дані природні радіонукліди (ПР) є джерелами гамма-випромінювання. Їх концентрації в ґрунтах, пісках і породах залежить від геологічних особливостей регіонів світу [1]. Будівельні матеріали, що виготовляються з різної сировини, варіюють за величиною питомої активності ПР. Люди більше 80 \% часу проводять в приміщеннях, отже, піддаються радіоактивного впливу ПР будівельних матеріалів протягом тривалого часу. Тому необхідна оцінка радіоактивності і радіологічних небезпек, пов'язаних з будівельними матеріалами [2]. Опромінення, отримане в приміщенні, дуже важливо як з точки зору його величини, так і необхідності оптимізації. Зовнішнє опромінення радіонуклідами цих матеріалів дуже важливо, однак їм часто нехтують з точки зору радіаційного захисту. Пропонуються заходи [3], що направлені на зниження рівня зовнішнього і внутрішнього опромінення людини в приміщенні: використання методів радіаційного захисту та їх оптимізація, дотримання будівельних норм, зменшення можливості еманації радону з пір будівельних матеріалів і підвищення обізнаності населення.

Аналіз літературних даних та постановка проблеми. Портландцемент є основним і важливим компонентом, використовуваним при будівництві будівель в багатьох країнах. Цей композитний матеріал виробляється з декількох видів сировини: вапняків, глини, гіпсу і залізної руди. Визначення активностей всіх сировинних компонентів, цементного клінкеру і кінцевого продукту портландцементу дуже важливо для забезпечення безпеки людини [4]. Залізорудні матеріали забезпечують присутність в цементі ${ }^{232} \mathrm{Th}$, вугіллі і летючій золі $-{ }^{226} \mathrm{Ra}$, глині $-{ }^{40} \mathrm{~K}$ [5]. При отриманні шлакопортландцементу з утилізацією промислових відходів зазвичай вивчають технічні та хімічні властивості отриманого матеріалу і дуже рідко - його радіологічні особливості [6]. В роботах $[4,5,7-15]$ методом гама-спектрометрії визначені питомі активності ПР у зразках цементів різного складу. Порівняльна характеристика радіологічних властивостей цементів приведена в таблиці 1. 
Таблиця 1. Радіоактивність цементів, виготовлених в різних країнах

\begin{tabular}{|c|c|c|c|c|c|c|}
\hline \multirow{2}{*}{\multicolumn{2}{|c|}{ Країна, матеріал }} & \multicolumn{3}{|c|}{$C_{i}$, Бк/кг (інтервал значень) } & \multirow{2}{*}{ Література } & \multirow{2}{*}{$C_{\text {eф.. }}$ Бк/кг } \\
\hline & & ${ }^{226} \mathrm{Ra}$ & 232 Th & $40 \mathrm{~K}$ & & \\
\hline \multirow{2}{*}{ Пакистан } & клінкер & $\begin{array}{c}51,1 \\
(32,9-69,3)\end{array}$ & $\begin{array}{c}23,2 \\
(22-24,4)\end{array}$ & $\begin{array}{c}258,4 \\
(243,1-273,7)\end{array}$ & \multirow{2}{*}{ [4] } & 103,5 \\
\hline & \multirow{15}{*}{ цемент } & $34,2(22,3-46,1)$ & $29,1(25,5-32,7)$ & $\begin{array}{c}295,1 \\
(228,2-362)\end{array}$ & & 97,4 \\
\hline \multirow{4}{*}{ Туреччина } & & 34,3 & 58,2 & 512 & [5] & 154,1 \\
\hline & & 33 & 16,7 & 239,5 & [7] & 75,2 \\
\hline & & 52 & 40 & 324 & [8] & 131,9 \\
\hline & & $\begin{array}{c}45,2 \\
(2,1-88,2)\end{array}$ & $\begin{array}{c}27,3 \\
(1,8-52,7)\end{array}$ & $\begin{array}{c}457,8 \\
(68,1-847,5)\end{array}$ & [9] & 84,8 \\
\hline \multirow{4}{*}{ Індія } & & $\begin{array}{c}19 \\
(9-28)\end{array}$ & $\begin{array}{c}35 \\
(21-43)\end{array}$ & $\begin{array}{c}406,7 \\
(280-554)\end{array}$ & [11] & 99,4 \\
\hline & & 54,1 & 39,3 & 149,8 & \multirow{3}{*}{ [12] } & 118,3 \\
\hline & & 28,6 & 23,5 & 180,7 & & 74,7 \\
\hline & & 31,3 & 41,2 & 233,9 & & 105,2 \\
\hline \multirow{2}{*}{ Нігерія } & & 66 & 126 & 589 & [13] & 281,1 \\
\hline & & 43,8 & 21,5 & 71,7 & [14] & 78,1 \\
\hline Єгипет & & $\begin{array}{c}33 \\
(16-50)\end{array}$ & $\begin{array}{c}14 \\
(11,6-16,4)\end{array}$ & $\begin{array}{c}45 \\
(19-71)\end{array}$ & [15] & 55,2 \\
\hline Сербія & & $<5-4938$ & $<3-63$ & $<10-3192$ & {$[16]$} & - \\
\hline Словаччина & & $\begin{array}{c}13,8 \\
(8,58-19,1)\end{array}$ & $\begin{array}{c}18 \\
(9,78-26,3)\end{array}$ & $\begin{array}{c}645,9 \\
(156,5-489,4)\end{array}$ & [17] & 92,3 \\
\hline Румунія & & $23,04-27,31$ & - & - & [18] & - \\
\hline
\end{tabular}

В останній графрі наведено критерій оцінки будівельних матеріалів - ефективна питома актив-

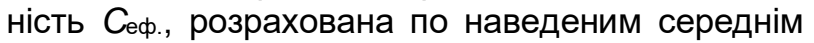
значенням $C_{i}$ радіонуклідів за формулою [19]

$$
C_{\text {эф. }}=C_{\mathrm{Ra}}+1,31 C_{\mathrm{Th}}+0,085 C_{\mathrm{K}} \text {, Бк/кг, }
$$

де $C_{R a}, C_{T h}, C_{K}-$ питомі активності ${ }^{226} \mathrm{Ra},{ }^{232} \mathrm{Th}$ та ${ }^{40}$ К відповідно в Бк/кг; $1 ; 1,31 ; 0,085$ - коефріцієнти, рівні відношенню потужностей дози в нескінченному просторі, створюваних при однакових питомих активностях ${ }^{232} \mathrm{Th}$ та ${ }^{226} \mathrm{Ra} ;{ }^{40} \mathrm{~K}$ та ${ }^{226} \mathrm{Ra}$ відповідно. Значення цих коефіцієнтів залежать від енергії і квантових виходів випромінювання ПР.

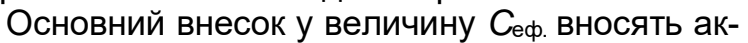
тивності ${ }^{226} \mathrm{Ra}$ та ${ }^{232} \mathrm{Th}$. Згідно [19] всі будівельні матеріали, наведені в таблиці 1, відносяться до першого класу радіаційної небезпеки $C_{\text {еф. }}<370$ Бк/кг і можуть використовуватися в будівництві без обмежень.

В роботі [15] вивчено безліч зразків цементу різного складу. Доведено, що цемент з добавками доменного шлаку має найвищий рівень радіоактивності, а білий цемент - найнижчий. У деяких зразках цементу зареєстрована низька активність ${ }^{137} \mathrm{Cs}[15,20]$. Представляють інтерес роботи по визначенню радіоактивності готового бетону і сировини для його виготовлення: наповнювачів, летючих зол і доменних шлаків [18, 21, 22].

Будівельні матеріали $є$ джерелами радону всередині будівель. Радіонукліди радону і їх дочірні продукти розпаду обумовлюють ризик опромінення через альфра-випромінювання. Через відносно більш високої концентрації радону в житлових будинках і більш тривалого часу, проведеного там, опромінення в приміщенні становить 90 \% від ризику раку легенів, викликаного радоном [23]. Біля 70-75 \% дози опромінення населення України від усіх джерел природної радіації припадає на радон [24]. В роботі [18] представлені дані по еманації радону із зразків бетону без добавок і 3 мінеральними добавками $10 \%$ і $20 \%$. Швидкість виходу радону значно більше в зразку з $10 \%$ добавки, і трохи менше - при наявності 20 \% добавки. Дослідження [18] підкреслює важливість структури пір, що утворюються при введенні добавок.

Велике число літературних даних стосується радіоактивності окремих будівельних матеріалів, набагато менше уваги приділено багатокомпонентним матеріалам, наприклад, бетонам, Y-випромінюванню їх ПР, еманації ізотопів радону.

Проблема дослідження - радіоактивні властивості багатокомпонентних бетонів і розрахунок дозових навантажень для людини при використанні бетонів. Досліджено 7 зразків бетону ВАТ "ДРСУ-33". Підприємство використовує бетон для будівництва автомобільних доріг і магістралей. Він же може застосовуватися і в цивільному будівництві в залежності від компонентного складу.

Задачі дослідження:

- експериментальне визначення питомих активностей ПР в багатокомпонентних бетонах; 
- розрахунок дози ү-випромінювання ПР бетонів і ефективної еквівалентної дози опромінення людей, які проживають в сучасних кам'яних приміщеннях;

- розрахунок середньої тканинної дози людини, обумовленої вдиханням ізотопів радону, в залежності від інтенсивності вентиляції в приміщеннях.

Матеріали дослідження, експериментальна частина. Гамма-спектрометричний аналіз шлаку виконаний за допомогою сцинтиляційного гамма-спектрометру СЕГ-001 «АКП-С», діапазон вимірюваних енергій, гамма-випромінювання якого становить від 50 до 3000 кеВ. Досліджувані проби містилися в вимірювальну посудину Марінеллі об'ємом 1 л. Час вимірювання активності природних радіонуклідів в середньому становив 2 години. Межа основної похибки вимірювання активності для геометрії «Марінеллі» $(P=0,95)$ не більше $25 \%$. Для обробки результатів вимірювань використовувалося програмне забезпечення Akwin.

Таблиця 2 включає експериментальні дані за питомими активностями радіонуклідів $C_{i}$, що отримані ү-спектрометричним методом, а також результати розрахунку сумарної питомої активності $C_{\text {сум. }}$ та $C_{\text {еф. }}$ бетонів (розрахунок за фрормулою (1)). Активності ${ }^{226} \mathrm{Ra}$ та ${ }^{232} \mathrm{Th}$ можна порівняти 3 даними таблиці 1 , активність ${ }^{40} \mathrm{~K}$ в зразках 1-3 дещо завищена.

Таблиця 2. Результати ү-спектрометричного аналізу зразків бетонів

\begin{tabular}{|c|c|c|c|c|c|}
\hline \multirow[t]{2}{*}{ № } & \multicolumn{3}{|c|}{$\begin{array}{c}C_{i,} \text { Бк/кг } \\
\left(\text { внесок в } C_{\text {сум }}, \%\right)\end{array}$} & \multirow{2}{*}{$\begin{array}{l}C_{\text {сум }} \\
\text { Бк/кг }\end{array}$} & \multirow{2}{*}{$\begin{array}{l}\text { Cecp., } \\
\text { Бк/кг }\end{array}$} \\
\hline & ${ }^{226} \mathrm{Ra}$ & ${ }^{232} \mathrm{Th}$ & ${ }^{40} \mathrm{~K}$ & & \\
\hline 1 & $\begin{array}{l}42,3 \\
(4,1)\end{array}$ & $\begin{array}{l}59,1 \\
(5,7)\end{array}$ & $\begin{array}{c}942 \\
(90,3)\end{array}$ & 1043,4 & 200 \\
\hline 2 & $\begin{array}{l}42,4 \\
(5,2)\end{array}$ & $\begin{array}{l}54,8 \\
(6,8)\end{array}$ & $\begin{array}{c}714 \\
(88,0)\end{array}$ & 811,2 & 175 \\
\hline 3 & $\begin{array}{l}46,4 \\
(4,5)\end{array}$ & $\begin{array}{l}61,2 \\
(6,0)\end{array}$ & $\begin{array}{c}920 \\
(89,5)\end{array}$ & 1027,6 & 205 \\
\hline 4 & $\begin{array}{l}24,9 \\
(5,3)\end{array}$ & $\begin{array}{l}46,2 \\
(9,8)\end{array}$ & $\begin{array}{c}398 \\
(84,9)\end{array}$ & 469,1 & 119 \\
\hline 5 & $\begin{array}{c}31,3 \\
(37,2)\end{array}$ & $\begin{array}{c}52,8 \\
(62,8)\end{array}$ & - & 84,1 & 101 \\
\hline 6 & $\begin{array}{l}22,2 \\
(4,7)\end{array}$ & $\begin{array}{l}35,7 \\
(7,5)\end{array}$ & $\begin{array}{c}416 \\
(87,8)\end{array}$ & 473,9 & 104 \\
\hline 7 & $\begin{array}{l}38,3 \\
(8,4)\end{array}$ & $\begin{array}{l}34,0 \\
(7,5)\end{array}$ & $\begin{array}{c}382 \\
(84,1)\end{array}$ & 454,3 & 115 \\
\hline
\end{tabular}

Сумарна питома активність зразків бетону коливається в межах 84,1-1043,4 Бк/кг. Найбільшу питому активність має зразок бетону № 1, а найменшу - зразок № 5. Основний внесок у величину

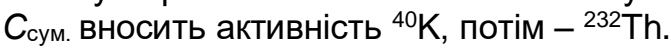

Для зразків бетону величина $C_{\text {eф. перевищує }}$ середню по СНД (93 Бк/кг [25]) та по Україні (106 Бк/кг [26]) окрім зразків № 5, 6. Однак всі досліджувані зразки бетону відносяться до I класу радіаційної небезпеки будівельних матеріалів, використовуваних в будівництві без обме-

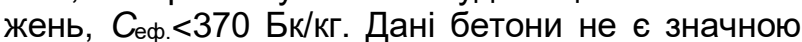
радіаційною небезпекою для населення. Внесок активностей радіонуклідів у величину $C_{\text {eф. }}$ зразків бетону № 1-3 зменшується в ряді ${ }^{40} \mathrm{~K}>{ }^{232} \mathrm{Th}>$ ${ }^{226} \mathrm{Ra}$, для інших зразків найбільший внесок обумовлює активність ${ }^{232} \mathrm{Th}$.

Розрахунок дозових навантажень для людей, які проживають в бетонних приміщеннях.

Ефективну еквівалентну дозу опромінення людей, які проживають в бетонних приміщеннях, розраховували за фрормулою [25]:

$$
D_{\text {пом. }}=4,74 \cdot \text { С эф. }, \text { мКЗв } / \text { рік. }
$$

Величину дози, отриману за рахунок ү-випромінювання ПР бетону знаходили за різницею [25]:

$$
\Delta D_{E P}=D_{\text {пом. }}-305, \text { мкЗв } / \text { рік, }
$$

де 305 мкЗв/рік - це доза, яку можуть отримати люди при знаходженні весь рік на відкритій місцевості в середніх широтах.

Таким чином, $\Delta D_{E P}$ являє собою додаткову дію ү-випромінювання ПР, обумовлену проживанням в кам'яних будівлях. Результати розрахунку річної ефективної еквівалентної дози опромінення людей і дози за рахунок ү-випромінювання ПР зразків бетонів наведені в таблиці 3.

Таблиця 3. Річна ефективна еквівалентна доза опромінення людей і доза-випромінювання ПР зразків бетонів, м3 в/рік

\begin{tabular}{|c|c|c|c|}
\hline № & $D_{\text {пом. }}$ & $\Delta D_{E P}$ & $D_{\text {50років }}$ \\
\hline 1 & 0,948 & 0,643 & 47 \\
\hline 2 & 0,83 & 0,525 & 42 \\
\hline 3 & 0,972 & 0,667 & 49 \\
\hline 4 & 0,564 & 0,259 & 28 \\
\hline 5 & 0,479 & 0,1747 & 24 \\
\hline 6 & 0,493 & 0,188 & 25 \\
\hline 7 & 0,545 & 0,24 & 27 \\
\hline
\end{tabular}

Доза за рахунок ү-випромінювання зразків бетонів № 1-3 перевищує сумарну річну дозу за рахунок дії ү-випромінювання будівельних матеріалів і еманації зі стін ізотопів радону (0,35 мЗв/рік [25]). За винятком зразків бетонів 13 розраховане значення $\Delta D_{E P}$ можна порівняти з літературними даними, м3в/рік: 0,326 - 0,515 для цементів [12]; 0,12 - 0,39 [15] та 0,21 - 0,31 [21] для бетонів різного складу. Індекс внутрішньої небезпеки, який має аналогічний зміст, розрахований [17], мЗв/рік: для портландцементу - 0,17, для шлакопортландцементу - 0,22 - 0,23, для пуцоланового цементу - 0,256.

Таким чином, за інтенсивністю ү-випромінювання ПР матеріалу викликають побоювання зразки бетону 1-3. 
За 50 років доза опромінення в приміщенні складе:

$$
D_{50 \text { років }}=D_{\text {пом. }} \cdot 50 \cdot 10^{-6} \text { Зв. }
$$

Величина $D_{50 \text { років }}$ (табл. 3) менша сумарної дози опромінення населення за рахунок ПР та проведення медичних процедур за 50 років (170 м3в [26]).

Розрахунок середньої тканинної дози людини, обумовленої вдиханням ізотопів радону, в залежності від інтенсивності вентиляції приміщення. Процес ексхаляціі радону можна розділити на два етапи: еманація атомів у внутрішні пори матеріалу і дифузія радону по поpax $з$ подальшим виходом з матеріалу. При зниженому повітрообміні і підвищеній або середній швидкості ексхаляціі об'ємна активність радону в повітрі приміщення може досягати високих значень. Для сучасних кам'яних будинків із залізобетонними перекриттями проникнення ${ }^{222} \mathrm{Rn}$ у повітря приміщення з ґрунту утруднене, і основним джерелом надходження ${ }^{222} \mathrm{Rn} €$ його ексхаляція 3 будівельних конструкцій. Максимально можливе виділення радону визначається величиною помноження концентрації ${ }^{226} \mathrm{Ra}$ у будівельному матеріалі на коефіцієнт еманації радону $(\eta)$ за наступною формулою [25]:

$$
\mathrm{C}_{\text {Rnmax }}=\frac{C_{R a} \cdot \rho \cdot \eta}{P}, \text { Бк/л, }
$$

де $\mathrm{C}_{\text {Rnmax }}$ - максимально можлива об'ємна активність радону в порах матеріалу, Бк/л; $C_{R a}-$ питома активність радію в матеріалі, Бк/кг; $\rho$ - щільність матеріалу, Кг/л; Р - пористість матеріалу, \%.

Мешканці будинків, де створилися умови для накопичення радону, можуть отримати високі індивідуальні дози опромінення легенів, що досягають 13 в/рік. Дозова межа для легень становить 15 м3в/рік [19]. Додаткове опромінення за рахунок еманації будівельних конструкцій 0,35 мЗв/рік, а за рахунок надходження радону з ґрунту під будівлею - 0,69 мЗв/рік. Середньорічна ефректина доза опромінення радоном для України з урахуванням чисельності населення в областях дорівнює 3,2 мЗв/рік [26].

Оцінку рівня виділення радону з бетону проводили відповідно до значення ефективної активно-

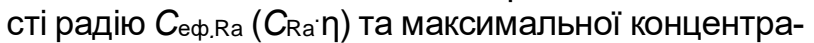
ції ${ }^{222} \mathrm{Rn}$ в порах зразків матеріалів $C_{\text {Rnmax. }}$ Не виявлено перевищення $C_{\text {еф. }}$ а для I класу радіаційної небезпеки будматеріалів $(22,2$ Бк/кг) $[19,25]$.

$C_{\text {Rnmax }}$ розраховували за рівнянням (4) з урахуванням даних $\rho=2,4$ кг/л; $\eta=0,095 ; P=8 \%$.

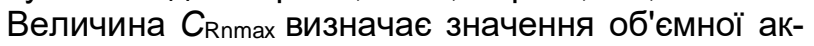
тивності радону в повітрі приміщень. Вона залежить від швидкості повітрообміну. Концентрація радону в повітрі приміщення $C_{\mathrm{Rn}}$ зазвичай становить $0,01 C_{\text {Rnmax }}$, що пов'язано зі стек-ефектом i присутністю відходів в будматеріалах у вигляді добавок.

Середню річну тканинну (легеневу) дозу опромінення людини за рахунок радону $\left(D_{\text {лег. }}\right)$ для невентильованих (5) і вентильованих (6) приміщень розраховували відповідно за формулами [25]

$$
\begin{gathered}
D_{\text {лег. }}=1,35 \cdot 10^{2} \cdot \mathrm{C}_{R n}, \text { Зв/рік, } \\
D_{\text {лег. }}=38 \cdot \mathrm{C}_{R n}, \text { Зв/рік, }
\end{gathered}
$$

де $C_{\mathrm{Rn}}$, Бк/л.

При розрахунку за даними фрормулами умовно приймають, що концентрація радону у повітрі, що вдихається постійна; радон знаходиться в рівноважному стані з продуктами розпаду. Дози розраховують в припущенні, що в легенях людини затримується близько $60 \%$ аерозольних часток, що несуть радіоактивні продукти розпаду ізотопів радону. Умови вентиляції приміщень при розрахунку за фрормулою (6) - зміна 0,001 об'єму повітря приміщення за $1 \mathrm{c}$.

Результати розрахунку наведені в таблиці 4. Всі зразки бетонів не можуть бути використані для будівництва будівель з відсутністю вентиляції, для них перевищено середнє значення еквівалентної дози (0,35 м3в/рік) [25]. Для зразків бетонів № 1-3, 7 при їх експлуатації в умовах інтенсивної вентиляції також спостерігалося перевищення $D_{\text {lungs }}>0,35$ мЗв/рік, тому досліджені матеріали не можуть бути рекомендовані для будівництва житлових будинків.

\begin{tabular}{|c|c|c|c|c|c|}
\hline \multirow[b]{2}{*}{ 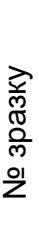 } & \multicolumn{5}{|c|}{ Величина } \\
\hline & 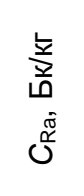 & 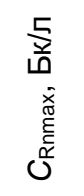 & $\begin{array}{l}\frac{5}{5} \\
\text { ம் } \\
\dot{\overline{\tilde{c}}}\end{array}$ & 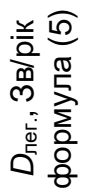 & 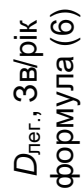 \\
\hline 1 & 42,3 & 1,21 & $1,21 \cdot 10^{-2}$ & 1,63 & 0,46 \\
\hline 2 & 42,4 & 1,21 & $1,21 \cdot 10^{-2}$ & 1,63 & 0,46 \\
\hline 3 & 46,4 & 1,32 & $1,32 \cdot 10^{-2}$ & 1,78 & 0,5 \\
\hline 4 & 24,9 & 0,71 & $7,1 \cdot 10^{-3}$ & 0,96 & 0,27 \\
\hline 5 & 31,3 & 0,89 & $8,9 \cdot 10^{-3}$ & 1,2 & 0,34 \\
\hline 6 & 22,2 & 0,63 & $6,3 \cdot 10^{-3}$ & 0,85 & 0,24 \\
\hline 7 & 38,3 & 1,09 & $1,09 \cdot 10^{-2}$ & 1,47 & 0,41 \\
\hline
\end{tabular}

Таблиця 4. Річна тканинна доза опромінення людей у вентильованому і невентильованому приміщенні

\section{Висновки:}

- Експериментально визначені питомі активності ПР у багатокомпонентних бетонах. Величина ефективної питомої активності свідчить, що всі зразки бетону відносяться до I класу радіаційної небезпеки і можуть використовуватися в будівни-

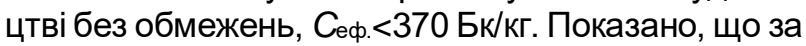


даними про радіоактивність зразків і масового вкладу їх окремих компонентів можливо визначити варіювання змісту інших компонентів бетону;

- Величина дози ү-випромінювання ПР зразків бетонів 1-3 перевищує середню сумарну річну дозу за рахунок дії ү-випромінювання будівельних матеріалів і еманації зі стін ізотопів радону. Зразки бетону 4-7 по інтенсивності ү-випромінювання не уявляють радіологічної небезпеки при використанні для будівництва будівель;

- Величина середньої тканинної (легеневої) дози людини, обумовленої вдиханням ізотопів радону при еманації будівельними матеріалами, показує неможливість використання для будівництва житлових приміщень усіх зразків бетону при відсутності вентиляції і зразків бетону 1-3, 7 при їх експлуатації в умовах інтенсивної вентиляції.

\section{Література:}

1. Shahbazi-Gahrouei, D., Gholami, M., Setayandeh, S. (2013). "A review on natural background radiation”, Adv. Biomed. Res., Iss. 2(3), p. 6, DOI: 10.4103/2277-9175.115821.

2. Buranurak, S., Pangza, K. (2018). "Assessment of natural radioactivity levels and radiation hazards of Thai Portland cement brands using Gamma spectrometry technique", Materialstoday: Proceedings, Iss. 5(6), pp. 13979 - 13988. DOI: 10.1016/j.matpr.2018.02.049/.

3. Butkus, D., Morkūnas, G., Pilkyte, L. (2015). "Ionizing radiation in buildings: Situation and dealing with problems", Journal of Environmental Engineering and Landscape Management, Iss. 13(2), pp. 103 - 107.

4. Aslam, M., Gul, R., Ara, T., Hussain, M. (2012). "Assessment of radiological hazards of naturally occurring radioactive materials in cement industry", Radiation Protection Dosimetry, Iss. 151(3), pp. 483-488, DOI:10.1093/rpd/ncs018.

5. Sezgin, N., Karakelle, B., Temelli, U. E., Nemlioğlu, S. (2019). "Natural Radioactivity and Hazard Level Assessment of Cements and Cement Raw Materials", In: Balkaya N., Guneysu S. (eds.) Recycling and Reuse Approaches for Better Sustainability. Environmental Science and Engineering. Springer, Cham., pp. 165 - 178.

6. Labrincha, J., Puertas, F., Schroeyers, W., Kovler, K., Pontikes, Y. et al. (2017), "7 - From NORM by-products to building materials", Naturally Occurring Radioactive Materials in Construction. Integrating Radiation Protection in Reuse (COST Action Tu1301 NORM4BUILDING), pp. 183 - 252, DOI:10.1016/B978-0-08-102009-8.00007-4.

7. Altun, M., Sezgin, N., Nemlioglu, S., Karakelle, B., Can, N., Temelli, U. E. (2017). "Natural radioactivity and hazard-level assessment of Portland cements in Turkey", Journal of Radioanalytical and Nuclear Chemistry, Iss. 314(2), pp. 941948, DOI:10.1007/s10967-017-5476-7.
8. Damla, N., Cevik, U., Kobya, A. I., Celik, A., Celik, N., Van Grieken, N. (2010). "Radiation dose estimation and mass attenuation coefficients of cement samples used in Turkey", Journal of Hazardous Materials, Iss. 176 (1-3), pp. $644-649$, DOI:10.1016/j.jhazmat.2009.11.080.

9. Solak, S., Turhan, S., Uğur, F. A. (2014). "Evaluation of potential exposure risks of natural radioactivity levels emitted from building materials used in Adana, Turkey", Indoor and Built Environment, Iss. 23(4), pp. 594 - 602, DOI:10.1177/1420326X12448075.

10. Mansour, H. L., Karim, M. S., Mishjil, Kh. A., Habubi, N. F. (2017). "Evaluation of Natural Radioactivity in Some Commercial Cement Samples by Using $\mathrm{Nal}(\mathrm{TI})$ Detector", Materials Focus, Iss. 6(3), pp. 339 - 344, DOl:10.1166/mat.2017.1412.

11. Sharma, A., Mahur, A. K., Yadav, M., Sonkawade, R. G., Sharma, A. C., Ramola, R. C., Prasad, R. (2015). "Measurement of Natural Radioactivity, Radon Exhalation Rate and Radiation Hazard Assessment in Indian Cement Samples", Physics Procedia, Iss. 80, pp. 135 - 139, DOI: 10.1016/ j.phpro.2015.11.086.

12. Vanasundari, K., Ravisankar, R., Durgadevi, D., Kavita, R., Karthikeyan, M., Thillivelvan, K., Dhinakaran, B. (2012). "Measurement of Natural Radioactivity in Building Material Used in Chengam of Tiruvannamalai District, Tamilnadu by GammaRay Spectrometry", Indian Journal of Advances in Chemical Science, Iss. 1, pp. 22 - 27.

13. Ademola, J. A., Farai, I. P. (2006). "Gamma activity and radiation dose in concrete building blocks used for construction of dwellings in Jos, Nigeria", Radiation Protection Dosimetry, Iss. 121(4), pp. 395 - 398, DOI:10.1093/rpd/ncl052.

14. Ademola, J. A. (2008). "Assessment of natural radionuclide content of cements used in Nigeria", J. Radiol. Prot., Iss. 28, pp. 581 - 588, DOI:10.1088/0952-4746/28/4/010.

15. Mahmoud, K. R. (2007). "Radionuclide content of local and imported cements used in Egypt", Radiol. Prot., Iss. 27, pp. 69 - 77, DOl:10.1088/0952-4746/27/1/004.

16. Pantelić, G. K., Todorović, D. J., Nikolić, J. D. et al. (2015). "Measurement of radioactivity in building materials in Serbia", J. Radioanal Nucl. Chem. Iss. 303(3), pp. $2517-2522$, DOI:10.1007/s10967-014-3745-2.

17. Eštoková, A., Palaščáková, L. (2013). “Assessment of Natural Radioactivity Levels of Cements and Cement Composites in the Slovak Republic", Int. J. Environ. Res. Public Health., Iss. 10(12), pp. 7165 - 7179, DOI:10.3390/ijerph10127165.

18. Cuibus, A., Cosma, C., Muntean, L. E., Kiss, Z. (2015). "Experimental studies on the radioactivity and exhalation rate of several concrete mixtures with additions", Rom. Journ. Phys., Iss. 60(7-8), pp. $1183-1192$. 
19. Нормы радиационной безопасности Украины (НРБУ-97), Киев, Министерство здравоохранения, 112 с.

20. Lee, E. M., Menezes, G., Finch, E. C. (2004). "Natural radioactivity in building materials in the Republic of Ireland", Health Phys., Iss. 86(4), pp. 378 - 383. DOI: 10.1097/00004032-20040400000007

21. Baltas, H., Kiris, E., Ustabas, I., Yilmaz, E., Sirin, M., Kuloglu, E., Gunes, B. E. (2014). "Determination of Natural Radioactivity Levels of Some Concretes and Mineral Admixtures in Turkey", Asian Journal of Chemistry, Iss. 26(13), pp. 39463952, DOI:10.14233/ajchem.2014.16045.

22. Kovler, K. (2017). "The national survey of natural radioactivity in concrete produced in Israel", J. of Environmental Radioactivity, Iss. 168, pp. 4653, DOI:10.1016/j.jenvrad.2016.03.002.

23. Chen, J. (2019). "Risk assessment for radon exposure in various indoor environments", Radiation Protection Dosimetry, ncy284, pp. 1-8, DOI:10.1093/rpd/ncy284.

24. Шутенко, Л. М. (2002). Міський житловий фонд: життєвий цикл і радіаційна безпека. Київ: Техніка, 2002. - 251 с.

25. Крысюк , Э. М. Радиационный фон помещений. Москва: Энергоатомиздат, 1989. - 120 с.

26. Коваленко, Г. Д., Рудя, К. Г. Радиоэкология Украины: Монография. Киев: Изд. «Киевский университет», 2001. - 167 с.

\section{References:}

1. Shahbazi-Gahrouei, D., Gholami, M., Setayandeh, S. (2013). «Obzor yestestvennogo fonovogo izlucheniya», Adv. Biomed. Res., Iss. 2 (3), s. 6, DOI: 10.4103 / 2277-9175.115821.

2. Buranurak S., Pangza K. (2018). «Otsenka urovney yestestvennoy radioaktivnosti i radiatsionnoy opasnosti marok tailandskogo portlandtsementa $s$ ispol'zovaniyem metoda gamma-spektrometrii», Material v tot den': Trudy, vyp. 5 (6), s. 13979 - 13988. DOI: 10.1016 / j.matpr.2018.02.049/.

3. Butkus D., Morkunas G., Pilkite L. (2015). «loniziruyushcheye izlucheniye $\mathrm{V}$ zdaniyakh: situatsiya i resheniye problem», zhurnal «Ekologicheskaya inzheneriya i upravleniye landshaftom», vyp. 13 (2), s. 103 - 107.

4. Aslam M., Gyul' R., Ara T., Khusseyn M. (2012). «Otsenka radiologicheskikh opasnostey prirodnykh radioaktivnykh materialov $v$ tsementnoy promyshlennosti», Radiatsionno-zashchitnaya dozimetriya, vyp. 151 (3), str. 483 - 488, DOI: 10.1093 / $\mathrm{rpd} / \mathrm{ncs} 018$.

5. Sezgin N., Karakelle B., Temelli U. Ye., Nemlioglu S. (2019). «Otsenka yestestvennoy radioaktivnosti i urovnya opasnosti tsementa i tsementnogo syr'ya», v: Balkaya N., Guneysu S. (red.) Podkhody k utilizatsii i povtornomu ispol'zovaniyu dlya povysheniya ustoychivosti. Ekologiya i inzheneriya. Springer, Cham., Str. 165 - 178.

6. Labrincha, J., Puertas, F., Schroeyers, W., Kovler, K., Pontikes, Y. et al. (2017), «7 - Ot pobochnykh produktov NORM do stroitel'nykh materialov», Yestestvenno radioaktivnyye materialy v stroitel'stve. Integratsiya radiatsionnoy zashchity pri povtornom ispol'zovanii (deystviye COST Tu1301 NORM4BUILDING), str. 183 - 252, DOI: 10.1016 / B978-0-08-102009-8.00007-4.

7. Altun M., Sezgin N., Nemlioglu S., Karakelle B., Dzhan N., Temelli U. E. (2017). «Otsenka yestestvennoy radioaktivnosti i urovnya opasnosti portlandtsementov v Turtsii», zhurnal radioanaliticheskoy i yadernoy khimii, vyp. 314 (2), s. 941 - 948, DOI: 10.1007 / s10967-017-5476-7.

8. Damla, N., Chevik, U., Kobya, A. I., Chelik, A., Chelik, N., Van Griken, N. (2010). «Otsenka dozy radiatsii i koeffitsiyentov oslableniya massy obraztsov tsementa, ispol'zuyemykh v Turtsii», zhurnal "Opasnyye materialy», vyp. 176 (1 - 3), s. 644 - 649, DOI: 10.1016 / j.jhazmat.2009.11.080.

9. Solak S., Turkhan S., Ugur F. A. (2014). «Otsenka potentsial'nykh riskov vozdeystviya urovney yestestvennoy radioaktivnosti, izluchayemykh stroitel'nymi materialami, ispol'zuyemymi v Adane, Turtsiya», «Vnutrennyaya i iskusstvennaya sreda», vyp. 23 (4), str. 594 - 602, DOI: 10.1177 / 1420326X12448075.

10. Mansur KH.L., Karim M.S., Mishil KH. A., Habubi, N.F. (2017). «Otsenka yestestvennoy radioaktivnosti $\mathrm{V}$ nekotorykh promyshlennykh obraztsakh tsementa $s$ ispol'zovaniyem Nal ( $\mathrm{TI}$ ) detektora», Materialy Focus, Iss. 6 (3), s. 339 - 344, DOI: 10.1166 / mat. 2017.1412.

11. Sharma, A., Makhur, A. K., Yadav, M., Sonkavade, R. G., Sharma, A. S., Ramola, R. S., Prasad, R. (2015). «lzmereniye yestestvennoy radioaktivnosti, skorosti vydykhaniya radona i otsenki radiatsionnoy opasnosti $v$ obraztsakh indiyskogo tsementa», Physics Methoia, Iss. 80, s. 135 - 139, DOI: 10.1016 / j.phpro.2015.11.086.

12. Vanasundari K., Ravisankar R., Durgadevi D., Kavita R., Kartikeyan M., Tillilivel'van K., Dkhinakaran B. (2012). «Izmereniye yestestvennoy radioaktivnosti $\mathrm{v}$ stroitel'nykh materialakh, ispol'zuyemykh $v$ Chengame Tiruvannamalayskogo rayona, Tamilnadu, s pomoshch'yu gammaspektrometrii», Indiyskiy zhurnal dostizheniy khimicheskoy nauki, vyp. 1, s. 22 - 27.

13. Ademola, Dzh. A., Faray, I. P. (2006). «Gamma-aktivnost' i doza oblucheniya v betonnykh stroitel'nykh blokakh, ispol'zuyemykh dlya stroitel'stva zhilishch v Dzhose, Nigeriya», Radiatsionnozashchitnaya dozimetriya, vyp. 121 (4), s. 395 - 398, DOI: 10.1093 / rpd / ncl052. 
14. Ademola, Dzh. A. (2008). «Otsenka yestestvennogo soderzhaniya radionuklidov $\mathrm{V}$ tsementakh, ispol'zuyemykh v Nigerii», J. Radiol. Prot., Iss. 28, str. 581 - 588, DOI: 10.1088 / 09524746 / 28/4/010.

15. Makhmud K.R. (2007). "Soderzhaniye radionuklidov $v$ mestnykh i importnykh tsementakh, ispol'zuyemykh v Yegipte», Radiol. Prot., Iss. 27, str. 69 - 77, DOI: 10.1088 / 0952-4746 / 27/1/004.

16. Pantelich G.K., Todorovich D.Dzh., Nikolich Dzh.D. i soavt. (2015). «Izmereniye radioaktivnosti v stroitel'nykh materialakh v Serbii», J. Radioanal Nucl. Khimreagent Vyp. 303 (3), s. 2517 - 2522, DOI: 10.1007 / s10967-014-3745-2.

17. Eshtokova A., Palashchakova L. (2013). «Otsenka urovney yestestvennoy radioaktivnosti tsementov $\mathrm{i}$ tsementnykh kompozitov v Slovatskoy Respublike», Int. J. Environ. Mestozhitel'stvo Zdravookhraneniye., Vypusk. $10 \quad$ (12), s. 7165 - 7179, DOI: 10,3390 / ijerph10127165.

18. Cuibus, A., Cosma, C., Muntean, L.E., Kiss, Z. (2015). "Eksperimental'nyye issledovaniya radioaktivnosti i skorosti vydykhaniya neskol'kikh betonnykh smesey s dobavkami», Rim. Journ. Phys., Iss. 60 (7-8), s. 1183 - 1192.

19. Normy radiatsionnoy bezopasnosti Ukrainy (NRBU-97), Kiyev, Ministerstvo zdravookhraneniya, $112 \mathrm{~s}$.
20. Lee E.M., Menezes G., Finch E.C. (2004). "Yestestvennaya radioaktivnost' $v$ stroitel'nykh materialakh v Irlandii», Health Phys., Iss. 86 (4), s. $378-383$.

21. Baltas KH., Kiris E., Ustabas I., Yilmaz E., Sirin M., Kuloglu E., Gunes B.E. (2014). «Opredeleniye urovney yestestvennoy radioaktivnosti nekotorykh betonov i mineral'nykh primesey $v$ Turtsii», Aziatskiy zhurnal khimii, vyp. 26 (13), s. 3946 - 3952, DOI: 10.14233 / ajchem.2014.16045.

22. Kovler K. (2017). «Natsional'noye issledovaniye yestestvennoy radioaktivnosti $v$ betone, proizvedennom v Izraile», J. Ekologicheskoy radioaktivnosti, vyp. 168, s. 46 - 53, DOI: $10.1016 /$ j.jenvrad.2016.03.002.

23. Chen, J. (2019). «Otsenka riska oblucheniya radonom v razlichnykh pomeshcheniyakh», Dozimetriya radiatsionnoy zashchity, ncy284, s. 1 - 8, DOI: 10.1093 / rpd / ncy284.

24. Shutenko, L. M. (2002). Mís'kiy zhitloviy fond: zhittêvyy tsikl í radíatsíyna bezpeka. Kiîv: Tekhníka, 2002. - $251 \mathrm{~s}$.

25. Krysyuk, E. M. Radiatsionnyy fon pomeshcheniy. Moskva: Energoatomizdat, 1989. $-120 \mathrm{~s}$.

26. Kovalenko, G.D., Rudya, K.G. Radioekologiya Ukrainy: Monografiya. Kiyev: Izd. «Kiyevskiy universitet», 2001. - 167 s.

\section{Аннотация}

\section{Радиоактивность бетонов как многокомпонентных строительных материалов}

\section{Э. Б. Хоботова, И.В. Грайворонская, Н.Н. Кириенко}

Оценка радиоактивности и радиологических опасностей, связанных с многокомпонентными строительными материалами является необходимой, так как в последнее время в производстве строительных материалов используются промышленные отходы, которые могут быть концентраторами природных радионуклидов. Строительные материалы являются источниками ү-излучения и поступления радона. Проблема исследования - радиоактивные свойства многокомпонентных бетонов и расчет дозовых нагрузок для человека при использовании бетонов. Гамма-спектрометрическим методом определены удельные активности ${ }^{226} \mathrm{Ra},{ }^{232} \mathrm{Th}$ и ${ }^{40} \mathrm{~K}$ в 7 образцах бетона. По величине эффективной удельной активности Сеф. $<370$ Бк/кг исследуемые образцы бетона относятся к I классу радиационной опасности и могут использоваться в строительстве без ограничений. Эффективная эквивалентная доза облучения за 50 лет для людей, проживающих в бетонных помещениях, меньше суммарной дозы облучения населения за счет природных радионуклидов и проведение медицинских процедур 170 мЗв. Однако по рассчитанным средним годовым тканевым (легочным) дозам облучения человека за счет радона для вентилируемых и невентилируемых помещений и по величине дозы за счет ү-излучения обнаружены образцы бетонов, которые не могут быть рекомендованы к применению в гражданском строительстве. Показано, что по данным о радиоактивности образцов и массового вклада их отдельных компонентов можно определить варьирование содержания других компонентов бетона. Строительные материалы являются источниками радона внутри зданий. Радионуклиды радона и их дочерние продукты распада обусловливают риск облучения через альфа-излучение.

Ключевые слова: природные радионуклиды, эффрективная удельная активность, бетон, гаммаизлучение, эманация радона. 


\begin{abstract}
The radioactivity of concrete as multicomponent building materials

\section{E. B. Khobotova, I.V. Hraivoronska, M.M. Kirienko}

Assessment of radioactivity and radiological hazards associated with multicomponent construction materials is essential since industrial waste, which may be natural radionuclide concentrators, has been used lately in the production of construction materials. Construction materials are the sources of $\mathrm{Y}$-radiation and ingress of radon. The subject of the research is radioactive properties of multicomponent concretes and calculation of human radiation exposure when using concretes. The gamma-spectrometric method determined the specific activities of ${ }^{226} \mathrm{Ra},{ }^{232} \mathrm{Th}$ and ${ }^{40} \mathrm{~K}$ in 7 samples of concrete. According to the value of the effective specific activity $\mathrm{C}_{\text {ef }}<370 \mathrm{~Bq} / \mathrm{kg}$, the concrete samples under research belong to class I of radiation hazard and can be used in construction without restrictions. The effective equivalent dose of radiation for people living in concrete premises for 50 years is smaller than the total dose of radiation of the population due to natural radionuclides and conducting medical procedures $170 \mathrm{mSv}$. However, based on the calculated average annual tissue (pulmonary) doses of human exposure with radon for ventilated and unventilated premises and on the dose level because of $y$-radiation, the samples of concrete were found that cannot be recommended for the use in civil engineering. It is shown that according to the data on the radioactivity of the samples and the mass contribution of their individual components, it is possible to determine the variation in the content of other concrete components. Building materials are sources of radon inside buildings. Radon radionuclides and their daughter decay products pose a risk of exposure through alpha radiation.
\end{abstract}

Keywords: natural radionuclides, effective specific activity, concrete, gamma-ray radiation, radon emanation.

\title{
Бібліографічне посилання/ Bibliography citation: Harvard
}

Khobotova E. B., Hraivoronska I.V. and Kirienko M.M. (2020). The radioactivity of concrete as multicomponent building materials. Engineering of nature management, (1(15), pp. $117-124$.

Подано до редакції / Received: 04.01.2020 